African Crop Science Journal by African Crop Science Society is licensed under a Creative Commons Attribution 3.0 Uganda License. Based on a work at www.ajol.info/ and www.bioline.org.br/cs DOI: http://dx.doi.org/10.4314/acsj.v24i1.11S

\title{
CULTURAL MANAGEMENT OF RUSSIAN WHEAT APHID INFESTATION OF BREAD WHEAT VARIETIES IN KENYA
}

\author{
M.N. NJUGUNA, M.H.G. MACHARIA MWANGI, J.K. KAMUNDIA, I. KOROS and G. NGOTHO \\ Kenya Agricultural and Livestock Organization - Njoro P. O. Box Private Bag 20107, Njoro, Kenya \\ Corresponding author: michael.njuguna@kalro.org
}

\begin{abstract}
Wheat (Triticum aestivum L.) is ecologically suited to East African countries and is the second important cereal after maize in Kenya. It is an important source of food, livestock feeds and income. However, its production (442,000 MT) does not meet annual domestic demand (1,750,000 MT), due to cereal aphids infestation. The most serious cereal aphid in Kenya is the Russian wheat aphid (RWA) (Diuraphis noxia Kurdjumov), causing yield losses of $>90 \%$ when not controlled. The objective of this study was to develop low cost cultural, sustainable and environmentally safe practices for the management of the RWA in East Africa. Treatments included nine varieties, three seeding rates and three rates of nitrogen application. Nine commercial wheat varieties, K. Tai, K. Kingbird, K Wren, K. Korongo, K. Hawk, K. Sunbird, Robin, K. Eagle, and NBWII were sown. Main plots were assigned to wheat varieties, sown at three seeding rates 75,100 and $125 \mathrm{~kg} \mathrm{ha}^{-1}$. Sub-plots were assigned to three rates of nitrogen, 75,100 and $130 \mathrm{~kg} \mathrm{~N} \mathrm{ha}^{-1}$, applied at tillering stage (GS 22). Variety K. Korongo supported the lowest aphid count of 3.6 per 5 plants; followed by K. Hawk (3.8) and Robin (2.9 aphids). Robin gave the highest grain yield $\left(2.9 \mathrm{t} \mathrm{ha}^{-1}\right)$, followed by K. Korongo $\left(2.7 \mathrm{t} \mathrm{ha}^{-1}\right)$ and K. Hawk $(2.5 \mathrm{t}$ $\mathrm{ha}^{-1}$ ). Application of $100 \mathrm{~kg} \mathrm{~N} \mathrm{ha}^{-1}$ and seeding at $100 \mathrm{~kg} \mathrm{ha}^{-1}$ were the best rates.
\end{abstract}

Key Words: Diuraphis noxia kurdjumov, nitrogen, Triticum aestivum

\section{RÉSUMÉ}

Le blé (Triticum aestivum L.) convient écologiquement aux pays de l'Afrique de l'est et est la deuxième céréale importante après le maïs au Kenya. C'est une source importante de nourriture, nourritures de bétail et revenu. Pourtant, sa production (442,000 MT) ne satisfait pas de demande domestique annuelle (1,750,000 MT), en raison de l'infestation de pucerons de céréale. Le puceron de céréale le plus sérieux au Kenya est le puceron de blé russe (RWA) (Diuraphis noxia Kurdjumov), en provoquant des pertes de production de> $90 \%$ sinon contrôlés. L'objectif de cette étude était de développer bas le prix les pratiques culturelles, durables et environnementalement sûres pour l'administration du RWA à Afrique de l'est. Les traitements ont inclus neuf variétés, trois taux seeding et trois taux d'application d'azote. Neuf variétés de blé commerciales, K. Tai, K. Kingbird, K le Troglodyte, K. Korongo, K. Faucon, K. Sunbird, Robin, K. L'aigle et NBWII ont été semés. Les complots principaux ont été alloués aux variétés de blé, semées à trois taux seeding 75, 100 et à $125 \mathrm{~kg}$ ha 1 . Les sous-complots ont été alloués à trois taux d'azote, 75,100 et de $130 \mathrm{~kg} \mathrm{~N} \mathrm{ha}^{-1}$, appliqué au stade tillering (GS 22). Variété K. Korongo a soutenu le compte de puceron le plus bas de 3.6 par 5 usines; suivi par K. Le faucon (3.8) et Robin (2.9 pucerons). Robin a donné la plus haute production de grain $\left(2.9 \mathrm{t} \mathrm{ha}^{-1}\right)$, suivi par $\mathrm{K}$. Korongo $\left(2.7 \mathrm{tha}^{-1}\right)$ et $\mathrm{K}$. Le faucon $(2.5 \mathrm{t}$ ha $^{-1}$ ). L'application de $100 \mathrm{~kg} \mathrm{~N}$ ha $^{-1}$ et de seeding à $100 \mathrm{~kg} \mathrm{ha}^{-1}$ était les meilleurs taux. 


\section{INTRODUCTION}

Wheat (Triticum aestivum L.) is an important staple food crop in East Africa with consumption levels ranging from $34 \%$ in Ethiopia to $5 \% \mathrm{~kg} /$ caput (Curtis, 2015). Wheat is ranked the second after maize in Kenya. It is an important source of both food and livestock feed (FAOSTAT, 2009). Kenya's annual domestic wheat requirement stands at 1,750,000 metric tonnes, against a production of 442,000 metric tonnes (USAID, 2014). Cereal aphids are among the most serious biotic constraint to wheat production. Several species of cereal aphids attack wheat, causing about $90 \%$ losses. The Russian Wheat Aphid (RWA) (Diuraphis noxia Kurdjumov) is the most destructive pest in Kenya, followed by Greenbug (S. graminum L.) (Macharia et al., 1997). RWA can cause up to $25-95 \%$ yield loss depending on the severity and stage of infestation (Macharia et al., 2012).

All commercial wheat varieties grown by farmers in East Africa are susceptible to RWA (Macharia et al., 1997). Currently, the main control is the application of aphicides (Macharia et al., 2012), which are costly especially to the small holder farmers. Hence, there is need for development of an integrated approach for the management of the cereal aphids, that will reduce the cost of production and keep the environment safe. The objective of this study was to develop cultural management practices which can be used in an Integrated Pest Management (IPM) strategy for the control of cereal aphids in wheat production.

\section{MATERIALS AND METHODS}

Field studies were conducted for three seasons, (2011-2013) at the Kenya Agricultural and Livestock Research Organisation (KALRO), Njoro $\left(35^{\circ} 31^{\times} \mathrm{E}\right.$ and $0^{\circ} 21^{\times} \mathrm{S}, 2,164 \mathrm{~m}$ a.s.l, AEZ LH3) in Kenya. The rainfall at this site is about $1012 \mathrm{~mm}$ per annum with mean maximum temperature of $27.9^{\circ} \mathrm{C}$, and mean minimum $7.9^{\circ} \mathrm{C}$. The site is characterised by Mollic Andosols type of soils (Jaetzold et al., 2010).

Treatments included nine varieties of wheat (K. Tai, K. Kingbird, K Wren, K. Korongo, K.
Hawk, K. Sunbird, Robin, K. Eagle, and NBWII), three seeding rates 75,100 and $125 \mathrm{~kg} \mathrm{ha}^{-1}$ and three rates of nitrogen $\left(75,100\right.$ and $\left.130 \mathrm{~kg} \mathrm{ha}^{-1}\right)$. They were laid out in a split-plot arrangement, in a randomised complete block design and replicated three times. Wheat varieties formed the main plots, seed rates the sub-plots, and $\mathrm{N}$ rates the sub-sub plots. Wheat was sown in rows using an experimental plot seeder in the main plots. The sowing time coincided with RWA peak infestation period.

Diammonium phosphate (18:46:0) was applied in all plots (farmer practice) at $100 \mathrm{~kg} \mathrm{ha}^{-1}$ to provide a starter nutrients. Crop management was done according to recommendations (KARI, 2005), with no application of insecticides. Five plants per plot were randomly selected, RWA identified and counted. RWA symptoms identified were rolled flag leaf, leaf/sheath purple colouration and fish hooked ears as reported by (Valiulus, 1986). RWA counts were transformed using formula " $x+1$ (Gomez and Gomez, 1984).

One $\mathrm{m}^{2}$ plots were randomly sampled using a quadrant, and harvested with a sickle. The plants were threshed using an experimental plot thresher. Data on tillers, spikes, biomass, thousand grain weight (TKW), harvest index (HI) and grain yield were taken and recorded. Harvest index was calculated as the ratio of grain yield to above ground dry matter at maturity (Metho and Hammes, 1999; Rashid et al., 2007).
Harvest Index $(\mathrm{HI}) \%=\quad$ Grain yield $\times 100$ Total biological yield

Grain moisture was adjusted to $12 \%$, using the grain weight was recorded; 1000 grains were counted and weighed. The data were pooled against season and analysed using the Statistical Analysis System (SAS) Version 9.4 (1994).

Data collected were subjected to the analysis of variance (ANOVA) at $5 \%$ level of significance. The treatment means were separated using Least Significant Difference (LSD). Yield (agronomic) benefits were calculated in order to establish whether use of different rates of nitrogen and seeding rates were useful practices to the farmer as follows: 
(i) Grain yield benefit = Grain yield ( $\mathrm{N}$ topdressed plots) - Yield (No N top-dressed plots)

(ii) Grain yield benefit $=$ Grain yield (higher seeding rate plots) - Yield (Lowest seeding rate plots).

\section{RESULTS AND DISCUSSION}

Significant $(\mathrm{P}<0.05)$ differences in aphid counts were observed among varieties (Table 1). NBW11 recorded the highest number of RWA; while K. Korongo gave the highest number of aphid counts. Tillers and spikes $\mathrm{m}^{-2}$, were also significant $(\mathrm{P}<0.05)$, for varieties. Njoro BWII gave the highest number of tillers and spikes; while K. Wren and K. Kingbird had the lowest number.

Seeding rates had significant $(\mathrm{P}<0.05)$ effects on both aphid counts (Table 2) and grain yield (Table 3). The highest aphid counts were recorded in the lowest seed rate of $75 \mathrm{~kg} \mathrm{ha}^{-1}$ and lowest infestation at $100 \mathrm{~kg} \mathrm{~N} \mathrm{ha}^{-1}$. The highest number of tillers (HI) and grain yield were recorded at 100 $\mathrm{kg} \mathrm{ha}^{-1}$; whereas the highest biomass accumulation, thousand kernel weight (TKW), and grain yield were recorded at the seed rate of $125 \mathrm{~kg} \mathrm{ha}^{-1}$.

Seeding rate of $125 \mathrm{~kg} \mathrm{ha}^{-1}$ resulted in highest grain yield compared with 75 and $100 \mathrm{~kg} \mathrm{~N} \mathrm{ha}^{-1}$, respectively (Table 4). There were no interactions, i.e., Variety X Nitrogen; Variety Seed Rates and Variety X Nitrogen X Seed Rates.

Nitrogen effect. Application of $\mathrm{N}$ at $100 \mathrm{~kg} \mathrm{ha}^{-1}$ resulted in the the highest $(\mathrm{P}<0.05)$ RWA counts, grain yield and number of tillers; while the highest biomass was recorded at $130 \mathrm{~kg} \mathrm{~N} \mathrm{ha}^{-1}$. Application of $\mathrm{N}$ at $75 \mathrm{~kg} \mathrm{ha}^{-1}$ gave the highest HI and TKW (Table 2). Application of nitrogen $100 \mathrm{~kg} \mathrm{ha}^{-1}$ gave the highest grain yield increase compared to 75 and $130 \mathrm{~kg} \mathrm{~N} \mathrm{ha}^{-1}$ (Table 2).

Seeding rates (SR). Highest RWA infestation was recorded in the lowest $S R, 75 \mathrm{~kg} \mathrm{ha}^{-1}$. Seed rate at $100 \mathrm{~kg} \mathrm{ha}^{-1}$ gave the highest tillers, HI and yield; whereas highest biomass accumulation and TKW were recorded at SR $125 \mathrm{~kg} \mathrm{ha}^{-1}$. Seeding at $75 \mathrm{~kg}$ $\mathrm{ha}^{-1}$ gave the highest aphid counts; while SR of

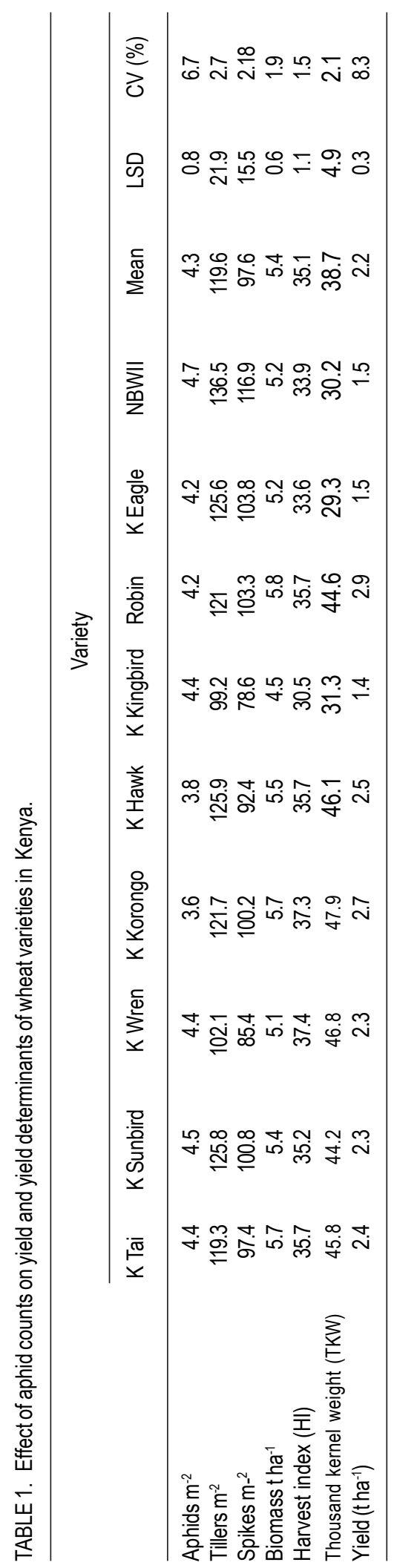


M.N. NJUGUNA et al.

TABLE 2. Effect of nitrogen on cereal aphid counts, yield and yield components at Njoro in Kenya

\begin{tabular}{|c|c|c|c|c|c|c|}
\hline \multirow[t]{2}{*}{ Parameter } & \multicolumn{3}{|c|}{ Seet rates } & \multirow[t]{2}{*}{ Mean } & \multirow[t]{2}{*}{$\operatorname{LSD}(0.05)$} & \multirow[t]{2}{*}{ CV $(\%)$} \\
\hline & 75 & 100 & 130 & & & \\
\hline Aphids $\left(m^{-2}\right)$ & 3.5 & 3.9 & 3.4 & 4.2 & 0.5 & 3.18 \\
\hline Tillers $\left(m^{-2}\right)$ & 112.8 & 133.9 & 114.3 & 119.7 & 15.5 & 2.68 \\
\hline Spikes $\left(m^{-2}\right)$ & 93.3 & 97.2 & 101.5 & 97.5 & NS & 2.08 \\
\hline Biomass $\left(\right.$ tha $\left.^{-1}\right)$ & 5.3 & 5.3 & 5.7 & 5.4 & 0.5 & 1.94 \\
\hline Harvest index $(\mathrm{HI})$ & 35.0 & 33.8 & 34.4 & 35.1 & 0.9 & 1.97 \\
\hline Thousand kernel weight (g) & 36.9 & 35.4 & 34.1 & 35.5 & NS & 2.1 \\
\hline Yield $\left(\right.$ tha $\left.^{-1}\right)$ & 2.1 & 2.5 & 2.4 & 2.3 & 0.3 & 20.8 \\
\hline Yield benefit $\left(\mathrm{kg} \mathrm{ha}^{-1}\right)$ & 0 & 400 & 233.3 & & & \\
\hline
\end{tabular}

NS = not significant

TABLE 3. Effect of seeding rates on cereal aphid counts, yield and yield components in a study at Njoro in Kenya

\begin{tabular}{|c|c|c|c|c|c|c|}
\hline \multirow[t]{2}{*}{ Parameter } & \multicolumn{3}{|c|}{ Seed rates } & \multirow[t]{2}{*}{ Mean } & \multirow[t]{2}{*}{$\operatorname{LSD}(0.05)$} & \multirow[t]{2}{*}{ CV $(\%)$} \\
\hline & 75 & 100 & 125 & & & \\
\hline Aphids $\left(m^{-2}\right)$ & 4.5 & 3.7 & 4.2 & 4.1 & 0.15 & 8.4 \\
\hline Tillers $\left(m^{-2}\right)$ & 112.7 & 123.8 & 122.6 & 119.7 & 0.5 & 2.6 \\
\hline Spikes $\left(m^{-2}\right)$ & 90.4 & 98.8 & 103.2 & 97.5 & NS & 2.08 \\
\hline Biomass (t ha-1) & 5.3 & 5.4 & 5.7 & 5.4 & 0.06 & 1.9 \\
\hline Thousand kernel weight (TKW) & 34.9 & 35 & 35.3 & 35.1 & 0.14 & 1.5 \\
\hline Harvest index $(\mathrm{HI})$ & 44.3 & 46.2 & 44.1 & 44.8 & 1.1 & 2.0 \\
\hline Yield $\left(\right.$ tha $\left.^{-1}\right)$ & 2.2 & 2.4 & 2.4 & 2.3 & 0.2 & 2.0 \\
\hline Yield benefit (kg ha-1) & - & 166.7 & 166.6 & & & \\
\hline
\end{tabular}

TABLE 4. Yield benefits due to Nitrogen application and seeding rates at Njoro in Kenya

\begin{tabular}{lrrr}
\hline $\mathrm{N}\left(\mathrm{kg} \mathrm{ha}^{-1}\right)$ & 75 & 100 & 130 \\
\hline Yield $\left(\mathrm{tha}^{-1}\right)$ & 2.1 & 2.4 & 2.3 \\
Yield benefit $\left(\mathrm{kg} \mathrm{ha}^{-1}\right)$ & - & 366.7 & 233.3 \\
& & & \\
Seeding rates & & & \\
& 2.2333 & 2.4 & 2.4 \\
Yield (t ha- $\left.{ }^{-1}\right)$ & - & 166.6 & 200 \\
Yield benefit (kg ha-1) & & & \\
\hline
\end{tabular}


$100 \mathrm{~kg} \mathrm{ha}^{-1}$ gave the lowest value. Seeding rate had a significant $(\mathrm{P}<0.05)$ effect on spikes $\mathrm{m}^{-2}$, biomass, HI and grain yield, but not significant on tillers. Seed rate at $125 \mathrm{~kg} \mathrm{ha}^{-1}$ gave the highest number of spikes and biomass production; followed by SR at $100 \mathrm{~kg} \mathrm{ha}^{-1}$. Moderate SR (100 $\mathrm{kg} \mathrm{ha}^{-1}$ ) was beneficial in the management of RWA in wheat production.

Variety K. Korongo gave the lowest RWA counts (3.6) (Table 1), contrary to Terri et al. (2003). Variety NBWII gave the highest RWA counts (4.7), followed by K Sunbird (4.5); although all the test varieties showed susceptibility but at different levels (Table 1). Results from this study concur with findings of Macharia et al. (2012) that all commercial wheat varieties grown in Kenya are susceptible to RWA. Findings from our study are in agreement with De Zutter et al.'s (2012) report where aphids showed preference to certain wheat varieties. In our study, it was apparent that RWA had preference for NBWII, compared to K Korongo which gave the lowest aphid counts.

Nitrogen at $100 \mathrm{~kg} \mathrm{ha}^{-1}$ gave the highest infestation of RWA; whereas $\mathrm{N}$ at 75 and $130 \mathrm{~kg}$ $\mathrm{N} \mathrm{a}^{-1}$ were not significantly $(\mathrm{P}>0.05)$ different. Our results showed that although infestation at $100 \mathrm{~kg} \mathrm{ha}^{-1}$ was high, the plant had adequate growth vigour and, hence, the highest grain yield. This observation concurs with Fluegel and Johnson (2001) report where different levels of nitrogen application had no significant $(\mathrm{P}>0.05)$ effect on aphid infestation. Nitrogen at $130 \mathrm{~kg} \mathrm{~N}$ $\mathrm{ha}^{-1}$ had no significant $(\mathrm{P}>0.05)$ effect on RWA infestation, grain yield and yield determinants, except biomass accumulation and HI. Nitrogen application at $130 \mathrm{~kg} \mathrm{~N} \mathrm{ha}^{-1}$ may not be beneficial to the grower since it did not increase grain yield, yet could be an additional cost of production.

Application of $\mathrm{N}$ at $100 \mathrm{~kg} \mathrm{ha}^{-1}$ resulted in the highest RWA counts and grain yield and highest number of tillers. The highest biomass accumulation was recorded at $130 \mathrm{~kg} \mathrm{~N} \mathrm{ha}^{-1}$. Application of nitrogen significantly increased grain yield and yield components, such as number of tillers, spikes, thousand kernel weight and grain quality. These results concurred with those reported by several other researchers (Parvez, 1989; Kent, 2003; Njuguna et al., 2010). In our study, the highest biomass accumulation was recorded at $130 \mathrm{~kg} \mathrm{~N} \mathrm{ha}^{-1}$, in agreement with Blumenthel et al.'s (2008) findings that total biological yield (biomass) above ground increases with nitrogen application, especially when applied at tillering.

Aphid counts varied significantly $(\mathrm{P}<0.05)$ with seeding rates, the highest counts being recorded in the lowest seeding rate. The results agrees with Infonet Biovision (2013) that low plant densities are more susceptible to aphid attacks. The high RWA infestation recorded at the lowest SR, $75 \mathrm{~kg} \mathrm{ha}^{-1}$, impacted heavily on critical wheat grain yield determinants, i.e. tillers, spikes, biomass accumulation, TKW, HI and ultimately grain yield. The high number of spikes recorded in the higher SR may have resulted from the high plant density contrary to Childress $e t$ al.'s (2012) postulation that yield components are impacted more by genetics than SR. The high number of tillers and spikes recorded in NBWII did not result in a significant increased grain yield, probably due to its attraction to high number of aphid infestation resulting in reduced biomass, because most of attacked tillers resulted in sterile and deformed ears. Tillers are important yield determinants in wheat, therefore, sterile tillers could have resulted in a reduction of grain yield in NBWII. This observation concurs with Burd and Burton (1992), Macharia et al. (2012) and Botha and Mustazilla (2004) reports postulating that severe aphid infestation causes high grain yield losses.

Results obtained from our study of different genetic potentials for RWA tolerance, yield components and grain yield are in agreement with those of Hassain et al. (2008). Kenya Korongo gave the highest biomass accumulation, $\mathrm{HI}$ (37.3) and TKW (47.9), and grain yield.The high susceptibility to RWA observed in NBWII may have caused herbivory damage, which reduces biomass by 55-77\% Miriki et al. (2009) and leaf area, disrupts the function of leaves and ultimately alters yield and productivity (Nabity et al., 2009).

\section{CONCLUSION}

Variety K. Korongo is the least attacked by the cereal aphids and NBWII is the most affected. Robin produces the highest grain yield; while NBWII gives the lowest grain yield. Nitrogen at 
$100 \mathrm{~N} \mathrm{~kg} \mathrm{ha}^{-1}$ has the highest aphid infestation, but also the highest grain yield. However, it appears that $\mathrm{N}$ is useful in making the plants tolerant to aphid infestation and, hence, high grain yield. Aphid counts vary with seeding rates, the highest counts being recorded in the lowest seeding rate. Higher SR and $\mathrm{N}$ levels are not beneficial to the grower, since they did not increase grain yield and yet could be additional cost of production. It could be concluded from the study that low plant densities (due to low SR) are susceptible to heavy attacks by the RWA. Nitrogen fertilisation may be a useful strategy for limiting both yield reduction and increased cost of production (pesticides use) caused by RWA in wheat crop.

\section{ACKNOWLEDGEMENT}

Authors acknowledge with appreciation the Eastern Africa Agricultural Productivity Project (EAAPP) and the Director General of Kenya Agricultural and Livestock Research Organization (KALRO) for financing this study. The Association for Strengthening Agricultural Research in Eastern and Central Africa facilitated the publication of this paper.

\section{REFERENCES}

Burd, J. D. and Burton, R.L. 1992. Characterisation of plant damage caused by Russian Wheat Aphid Diuraphis noxia (Homoptera: Aphididae). Journal of Economic Entomology 85:2017-2022.

Botha, C.E.J. and Mastazilla, B. 2004. Reduction in transport in wheat (Triticum aestivum) caused by sustained phloem feeding by the Russian wheat aphid diuraphis noxia. South African Journal of Botany 70:249-254

Childress, M.B., Griffey, C.A., Hall, M.D. and Thomason W.E. 2012. Seeding rate effects on yield and yield components of bread wheat cultivars in the mid-Atlantic USA. (2010) Plant Management Network.

Curtis, B.C. 2015. Wheat in the world. www.fao.org/docrep/006/y4011e/ y4011e04.ht. 9/2/2016

FAOSTAT, 2009. Kenya production potential. Kenya wheat database, ^'’Faostat"' (http:// faostat.org/site/526/default.aspx). Accessed 3 August 2015.

Fluegel, M. S. and Johnson J.B. 2001. The effect of soil nitrogen levels and wheat resistance to the Russian Wheat Aphid Diuraphis Noxia (Homoptera Aphididae). Journal of the Kansas Entomological Society 74(1):49-55.

Gomez, A.K. and Gomez, A.A. 1984. Statistical Procedures for Agricultural Research. Second Edition 1984. John Willey \& Sons, Inc.

Infonet Biovision 2013. Wheat General Information and Agronomic Aspects. 0http:/ /www.infonet_biovision.org/default/ct/168/ crops.

Hussain I., Khan, M.A. and Khan, A.E. 2008. Bread wheat varieties as influenced by different rates of nitrogen levels. Journal of Zhjiang Univ Sci. B. 7(1):70-78.

Jaetzold, R., Schmidt, H. and Honetz, B. 2010. Farm Management Handbook of Kenya Vol. II. Natural Conditions and Farm Management Information. $2^{\text {nd }}$ Edition. PART B. Central Kenya.

Kent, D.O. 2003. Farm Management: Principles and Strategies. pp. 102.

KARI, 2005. Crop Management: In: Crop Production Handbook for Wheat, Oil crops and Horticulture.

Macharia, M., Muthangya P.M. and Wanjama, J.K. 1997. Barley yellow dwarf virus Report 1994-1997. Kenya Agricultural Research Institute, National Plant Breeding Research Centre, Njoro, Kenya.

Macharia, M., Gethi, M., Ngari, C.M. and Njuguna, M. 2012. Impact of climate change on wheat insect pests in Kenya. In: Quilligan, E., Kosina, P., Downs, A., Mullen, D. and Nemcova, B. (Eds.). Wheat for food security in Africa Conference. October 8- 12, 2012, Addis Ababa, Ethiopia.

Metho, L.A. and Hammes, P.S. 1999. The harvest index of individual ears of four South African wheat (Triticum aestivum L.) S. Afr. J. Plant and Soil (Press)

Miriki, M., Ansley, J., Michels, J. and Elliots, N. 2009. Grain and vegetative biomass reduction by the Russian wheat aphid in Winter Wheat. Southwest Entomologist 34(2): 131-139. Doi http://dx.doi.org/10.3958.0203. Accessed 3 August 2015. 
Njuguna, M.N., Munene, M., Mwangi, H.G., Waweru, J.K. and Akuja, A.K. 2010. Effect of seeding rate and nitrogen fertiliser on wheat grain yield in marginal areas of eastern Kenya. Journal of Animal and Plant Sciences 7(3):834-840. Website http://www. biosciences.elewa.org/JAPS

Nabity, D.P., Zavala, J. A. and DeLucia, H. E. 2009. Indirect suppression of photosynthesis on individual leaves by arthropod herbivory. Annals of Botany 2009. Feb; 103(4): 655-663. Doi 10.1093/aob/Mcn127. Accessed August 3, 2015.

Pavez, S.D. 1989. Effect of seed size and sowing rate of wheat on plant development and some yield components. Simiente 59 (1-2):21-29

Rashid, A., Bilal, H. and Khawar, J. 2007. Improving crop harvest index. http// archives.dawn.com/2007/10/01/ebr6.htm.

Riedell, W.E. 2008. Tolerance of wheat to RWA: Nitrogen fertilisation reduces yield loss. Journal of Plant Protection 13 (5):579-584 DOI: 10.1080/01904169009364101.

SAS $^{\circledR}$ 9.4, 1994. SAS.Users, Guide Statistics. SAS Institute Inc. Cary, NC., USA.

Silvina, I. G., Hugo, O.C. and Santiago, J.S. 2005. Biomass production, nitrogen accumulation and yield in wheat under two tillage systems and nitrogen supply in the Argentine Rolling Pampa. World Journal of Agricultural Sciences 1 (1): 36-41.

Sara, Z., Hossein, A., Mohammad, R.B. and Alireza, S. 2010. Effect of nitrogen fertilisation on life table parameters and population growth of Brevicoryne brassicae. Bulletin of Insectology 63 (1): 39-43.

Terri, L., Randolph, F.B., Peairs, F.B., Kroeing, M.K., Amstrong, J.S., Hannon, W.R., Walker, B.C. and Quick, J.S. 2003. Plant damage and yield response to the Russian Wheat Aphid (Homoptera Aphididae) on susceptible and resistant winter wheat in Colorado. Journal of Economic Entomology 96 (2): 352-360.

USAID. 2014. USAIDA Foreign agricultural service grain Report. Global Agricultural Information Network. www.gain.fas. usda.gov/Recent Gain Publications/Grain and Feed Annual_Nairobi_Kenya_4-8 2014.pdf

Valiulus, D. 1986. Russian Wheat Aphid: A new pest that may be here to stay. Agrochemical Age 30: 10-11.

Zutter, De N., Audnaert, K., Haesaert, G. and Smagghe, G. 2012. Preference of cereal aphids for different varieties of winter wheat. Arthropod - Plant Interactions. DOI 10.1007/ sl1829-9184-5 